\title{
Supplementing the Dangerous Supplement: Auto-(bio)graphical Fragments from the Diary of a Female Cigarette Addict
}

\author{
Anna Antonopoulos
}

\section{Comme supplément au supplément dangereux: Des fragments auto-(bio)graphique du journal d'une cigarettomane}

S'inspirant du théorie Derridean de l'écriture comme supplément, comme 'pharmakon,' ce texte explore le supplément du 'grammata,' 'les marques externes de la mémoire,' comme 'remède' à l'intoxicatic par la nicotine. La plume se substitue à la cigarette. Leje(u) du signifiant et du cignifiant se déploie dans un procès où le sujet se construit et se dé(con)struit dans un (con)texte où les signes du corps se (trans)forme.

As a comment on the expression 'that dangerous supplement' used by Rousseau in his Confessions to describe masturbation, Jacques Derrida follows the consequences of the way in which the word supplément has two meanings in French: 'addition' and 'replacement'. ${ }^{1}$ In a subsequent turn, Derrida elides the 'Plato-SaussureRousseau' trio on language to fathom the idea of writing as pharmakon - playing upon the double articulation of the Greek pharmakon in the sense of both a 'poison' and a 'cure'. ${ }^{2}$

While this theme of writing (language / letter / signifier) as substitution has a history of illustrious precedents, the equivalence of writing and the pharmakon is still relatively unexplored. To date, Plato's Phaedrus and its myth of the god Theuth's invention of the grammata, the 'external marks' of memory, remains the master narrative. ${ }^{3}$ Given to the Egyptian king of Thebes as the ingenious rescue from the weakness of the spoken word, their subsequent devaluation by the king as 
a form of substitution and 'false remedy', has since 'fixed' these marks in an internal ambiguity. A narrative that cuts across the scene of writing as both a 'poison' and a 'cure' this is one that has yet to be brought in line with the scene of language itself and the psychoanalytic construction of the subject as structured absence.

Writing herein is 'experimental' in that words figure as the supplement to the dangerous supplement of cigarette smoke. Working to 'replace' a pharmakon that had been poisoning my system for over twenty years, it served at the same time to unmask its equally important function as a 'cure' the removal of which exposed me to a danger of a much greater kind than that attributed to the toxic substances of tar and nicotine. The danger of aphanisis that took shape in the absence of any material sign of subjectivity became the source of an anxiety and a despair to which only 'writing', grammata, the 'external marks' of memory, could be the remedy. This is how a project of supplementing the dangerous supplement was born in which 'writing' as pharmakon figured not only as a replacement of smoking, but in addition as the text of a new self-representation.

The alarming success of my experiment (substitution of writing for smoking) not only raises questions about the 'toxic' nature of smoking as a form of signifying practice. More importantly, it raises questions about the function of writing as 'supplement' and its relation to the construction and de-construction of subjectivity in language. In the transparency of writing as pharmakon, that effects the fantasmical slide from a preoccupation with smoking as signification to that of writing, new connections in theorizing the subject in language can be forged. ${ }^{4}$ By grafting the subject-in-writing as supplement to the psychoanalytic subject-in-language this experiment raises the pharmakon as the privileged site for the construction and de-(con)struction of the Self. In the equivalence between writing and smoking the rudimentary outlines appear of a subject within the language as a subject-in-process. Moreover, in the 'additional' gendered exploration of the pharmakon - as the cigarette / the stylus / phallus - the 'écriture' of a 'femininity-in-crisis' ${ }^{5}$ becomes the critical site of the supplement (replacement? addition?) to the (dangerous / phallogocentric) PlatoRousseau-Saussure-Derrida connexion. Intersecting with the psychoanalytic articulation of feminine subjectivity as at once a 'lack' and an 'excess' the problematic of the pharmakon emerges as a fertile ground upon which to explore the production and reproduction of 
subjectivity in language as well as woman's over-determined (negative) relation to the Symbolic, one which poses the pharmakon (and writing as pharmakon) as the equally privileged site of a counterlanguage, and an écriture, that disrupts the binary fixing of feminine subjectivity in language.

It is principally as an incitement to discourse and conversation in that direction and as 'supplement' to the 'dangerous supplement' of Plato-Rousseau-Saussure-Derrida, that I am offering the following auto-graphein of the female cigarette addict. While in no way an academic treatise (as a matter of fact I had yet to study in any depth the psychoanalytic discourse on the subject in language), or even in any sense a complete auto-(bio)graphical presentation, the fragments that appear scrawled together here nonetheless echo the classic psychoanalytic themes of death, desire and subjectivity as they trace themselves across the face of the feminine Imaginary. Excerpted from a fuller auto(bio)graphical work that covers seven years of struggle with the problem of dependency and representation, the fragments that appear here form the (con)text of a new self-representation. Cast out of the immediate and very real (Real?) dimension of a psyche / subject-in-crisis, these cryptic lines, inscribed in small cylindric segments on pocket notebooks the size of a king-size pack, anticipate the process of writing as 'cure'. It is here, at the lived site of a lost object, a lost sig / cig-nifier and a lost practice of sig / cig-nification, where the germ of an equivalence between the stylus / cigarette / phallus was born. Here too, at the heart of an 'experiment' with writing about cigarettes as a supplement to smoking them, that 'smoking', and hence 'writing', become the privileged site for the construction and de-construction of a female subjectivity.

With the exception of their titles and the use of square brackets for the inclusion of subsequent queries, the fragments that follow are unchanged. Not wishing to disturb the evolution of a text / process that wrote / revealed itself only gradually, I have tried as much as possible to conserve its original expression. Thus while many of the ideas expressed in these fragments have been resumed, taken up and developed in more sophisticated and possibly more precise ways, rather than a selection of 'best' segments, I have chosen instead to present and simply set forth the 'first' spontaneous etchings of that process / text. 
The Mystic Smoking Pad

A pad of paper

and a pen:

the kit of the ex-smoker,

the way of self-revelation, exploration, and delight!

\section{The Sig / Cig-nifying Chain}

A cigarette -

a beginning, a middle, and an end

that ties together the loose ends of time.

The gaps between the moments,

thoughts,

activities,

without much effort,

though.

Imagine having to invent the moment, and to imagine the beginning,

the middle, and the end.

Sometimes, it's enough to take a deep breath, in.

How many breaths compose a cigarette?

A Craven-'A'-Blue King-Size Cigarette?

\section{The Materiality of the Sig / Cig-nifier}

I still tell myself:

I'll have a 'cigarette'....

I'll have a 'cigarette' and think about it....

Let me have a 'cigarette' first...' 
After this 'cigarette'....

It's a moment;

moments.

My 'cigarette'.

An allowance.

I take it.

I call it 'a cigarette' -

I don't smoke though.

I 'have' a cigarette.

\section{Smoking and Sig / Cig-nification}

I guess I 'smoke' in this pad.

Everybody needs to smoke.

(Let off 'steam'?)

I smoke with a paper and a pencil, and a deep breath of air now -

\section{The Dangerous Supplement}

I feel fine, though I'm not sure.

I'm ready to learn, find out.

I am finished with cigarettes.

I want to stop smoking cigarettes.

For many, many reasons of course, but most of all because I have started to think that smoking cigarettes is repressive.

I have begun to think it is repressive of $\mathrm{CHI}$ breath [the life-force].

An input with no output.

At least for me, 
Supplementing the Dangerous Supplement $\cdot 127$

because I started smoking before I found my CHI [key?].

A tumor in the lungs-

what better picture for the obstruction / suppression of breath.

Some smokers have the profile of a cancer personality.

Outrageous?

Reich didn't think so.

Writing and the Art of Giving Up Smoking

[Write]

one

complete

thought

for

every

unsmoked

cigarette -

one complete cigarette-thought!

The Subject of Smoking

A thought from another day:

The pros of giving up smoking: infinite.

The cons: only one-I am not smoking anymore.

Not smoking,

giving up smoking,

quitting smoking, stopping smoking.

What do they all have in common?

My last cigarette was on Tuesday, March 2. 


\section{Supplementing the Dangerous Supplement}

On the non-smoker,

the smoker,

and the ex-smoker.

The smoker's awareness

of time and space

is different from the non-smoker's.

His cigarettes divide and organize his time,

his smoke divides and delineates his space.

The ex-smoker has the same awareness

of time and space as the smoker,

without having the instruments [signs] -

cigarettes and the smoke -

with which to express that awareness.

He must invent them.

The Sig / Cig-nifying Subject

Still,

the writer who smokes -

somehow realer,

seriouser,

more human.

Badness,

rebellion,

thinking for oneself.

\section{Constructing Masculinity No.1}

Individualistic -

this is how the women

who smoked around me 
appeared to me then.

They were 'bad' women, smoking women. masculine women. free women, etcetera, etcetera.

Except that I know now that they weren't. It's not being bad but being strong. Smoke weakens.

\section{Constructing Masculinity No. 2}

I.

Smoking is assertive.

A cloud of smoke preludes the person.

Some women wear cigarettes

like others wear perfume.

You can't ignore them....

II.

Sometimes, even if you don't want to be noticed, and want to smoke,

there is a problem.

Are there more significant ways of asserting oneself?

III.

Cigarettes,

smoke,

masculinity.

IV.

It's true.

Maturity equals masculinity.

That's why women smoke, 
and why men smoke.

V.

Masculinity,

presence,

daring,

dureness.

The cigarette,

spirit of an Age.

The Language of Desire No. 1

A craving

[Craven-'A'?]

is a craving.

I crave food

as much as smoke

as much as anything.

I crave therefore

I am.

To satisfy one

is to satisfy

all.

Which craving shall I choose?

\section{The Excess}

I have no good memories of myself smoking cigarettes, but cigarettes in my memory will be good forever.

Am I more than my cigarettes? 
Cigarettes:

companions, dependents,

that you have to care for,

guard, safekeep,

never ever forget,

or leave behind.

Alter-egos.

I miss my private cigarettes the most.

\section{Writing the Self}

I.

The gasping,

grasping,

never finding feeling taking over....

stop, center, think....

I pay no attention.

The way of the ex-smoker will be different.

Work to be done -

I must pause to think.

And it all begins here....

with the reflections herein.

The NEW WAY.

The new ME.

II.

I don't really miss smoking

as much as

I miss the me that smoked.

I feel lost

disoriented

not smoking.

Disoriented, meaning

I don't know where I'm coming from 
or where I'm going to.

I learn from my experience

in disorientation.

Like an amnesiac.

An unfamiliar ME

emerging.

Looking

for sign-posts.

There not being any.

Must find them

then.

Put them up

as we go along....

Because I'm on

a different WAY.

Nothing I learned or used applies

today.

Here is nowhere

because it is not

where I WAS

before.

III.

I don't know how much of my book I can write.

It may be that $I$ have not been a writer until now.

I must improvise, make up the RULES,

stay open.

Find things out.

Who am I now [?],

who was I then before?

Just as when I smoked I learned....

slowly carved up the identity that is left sitting

in the fridge today....

though, actually,

it was duMaurier 
first.

$\mathrm{Ah}$,

the WAY of the smoker!

To write about that!

The Language of Desire No. 2

Also, I crave therefore I gratify [graffiti?]

therefore I smoke.

I'm craving....

I want,

need

to smoke.

But what do I crave?

I look more closely....

many, many things again.

Food right now.

Chocolate food.

Luckily, in two weeks I can satisfy this craving.

So long as it's not a craving for cigarettes....

But then, what might that be for?

A deep breath?

A bridge?

Death?

\section{Death of the Grand Sig / Cig-nifier}

The smoker allows himself [sic] to crave death because, secretly, he [sic] thinks that he's [sic] immortal. 
He [sic] courts death because

he [sic] thinks that

he [sic] can conquer death -

he's [sic] a Living Death....

and so he [sic] is assured.

But when his [sic] assurance starts to wear thin....

when guilt begins to take its place....

when once, he [sic] put his cigarette out

before he [sic] finished it...

he [sic] starts to change.

he [sic] starts to doubt.

\section{Death of the Subject}

An evening at home spent eating -

Now, I imagine what it would have been like if I didn't eat.

I'd want to smoke.

And if I didn't smoke?

I'd agonize.

Feel incomplete,

like I'd forgotten something important

and didn't know what it was.

My mind desperately seeking to grasp that feeling

of assurance -

of smoke in my breath -

hot air,

visible air,

air that touches my lungs -

that I feel therefore I AM.

That I am ALIVE-

and that escapes me still.

Surely, I'm not DEAD?

But I am imperceptible to myself now.

The pain of smoking is gone. 
The veil has lifted:

and,

HORRORS -

THERE

IS

NOTHING

UNDERNEATH.

I want to be BIG.

So as to be sure that I am

THERE.

But was I certain that I was there before?

Or simply certain that the smoke,

the cigarettes,

the ashes and the dust was there?

No, I was there -

the smoker of the cigarette.

The one that turned the dry leaves

rolled in paper

into dust.

The one that emptied out the ashtrays,

filled them up again....

A new beginning was a new cigarette.

Now a new beginning is a complicated matter-

Still trailing in the butt-ends of my days and ways.

Twenty years of butt-ends....

\section{Notes}

1. Jacques Derrida, Of Grammatology, trans. Gayatri Chakravorty Spivak (Baltimore: John Hopkins UP, 1976), 141-158.

2. Jacques Derrida, Dissemination, trans. Barbara Johnson (Chicago: $U$ of Chicago P, 1981), $101 \mathrm{ff}$.

3. Plato: The Collected Dialogues, ed. Edith Hamilton and Huntington Cairns (Princeton: Princeton UP), 520:275.

4. Freud is one who has gone so far as to devise a topographical metaphor of 'psychic writing' in which the unconscious itself is visualized as a writingmachine. See his essay 'A Note Upon the Mystic Writing-Pad' (1925), in Sigmund Freud: On Metapsychology (Harmondsworth: Pelican Freud Library, 1984), 429-433. This, of course, offers up an interesting alternative to the 


\section{6 - Tessera}

Lacanian theorization of the materiality of language in terms of the Symbolic construction of subjectivity itself.

5. Cf. Hélène Cixous and Catherine Clément, The Newly Born Woman, trans. Betsy Wing (Minneapolis: U of Minnesota P, 1986). 